\title{
EC Banana Dispute and the GATT/WTO
}

\section{Norio KOMURO*}

\section{Introduction}

The notorious banana saga has been dealt with on three levels: the GATT/WTO, the EC Court of Justice ("ECJ") and EC Member States' courts. These different fora did not render convergent decisions, but rather complicated the matter further. Clearly, the EC banana regime favoured EC and ACP bananas to the detriment of third-country bananas. GATT/ WTO panels supported arguments by non-ACP parties and found the banana regime to be inconsistent with EC's obligations under GATT/WTO nondiscrimination rules. However, the ECJ has rejected legal challenges against the EC regime, thus giving rise to conflicts with GATT/WTO findings and national courts.

This paper reviews the banana dispute before the GATT/WTO, the ECJ and national courts to compare each judicial control over the EC trade measure.

\footnotetext{
* Professor of International Economic Law, Kobe University Law School. The author would like to thank William J. Clinton, Gerrit Schohe, Christoph Arhold and Mark D. Nguyen for their valuable comments on an earlier draft. Any remaining faults are the sole responsibility of the author.
} 


\section{The EC Banana Regime}

\section{Previous National Banana Import Regimes and the First GATT Panel Report}

(1) Fragmented Banana Market

Prior to the establishment of the common market organization for bananas, the Community banana market was fragmented by different national import regimes. Whereas Member States, which had the domestic banana production or traditionally imported bananas from their ex-colonies, closed their markets to third-country bananas (i. e. Latin American bananas), other Member States had more open market policies.

In closed market countries such as France, the United Kingdom, Greece, Italy and Portugal, imports of third-country bananas were restricted by quantitative restrictions and licensing requirements. The demand in these countries was met by domestic bananas and/or ex-colonies' bananas that were now African, Caribbean and Pacific (ACP) states' bananas. Imports from all ACP states were granted duty-free access to the Community following the Fourth Lomé Convention concluded in 1989 between the EC and ACP states. In brief, closed market Member States restricted imports of Latin American bananas to protect domestic bananas and ACP bananas.

In contrast, Germany, Benelux, Denmark and Ireland opted for open market policies for banana imports. They imported bananas from the most competitive sources, i. e., Latin America. Imports of Latin American bananas were not subject to quantitative restrictions. They were, however, subject to a customs duty of 20 percent ad valorem consolidated within the framework of the GATT in Benelux, Denmark and Ireland. The exception was Germany, which enjoyed a special arrangement concluded at the beginning of the EEC. The so-called Bananas Protocol, which was attached to the Implementing Convention based on ex Article $136 \mathrm{EC}$, permitted Germany to apply a duty-free import quota to third-country bananas. The 
quota was annually adapted to the level of estimated consumption in Germany and accounted for approximately one-third of the Community bananas imports.

(2) The First GATT Panel Report ("Bananas I")

The national banana import regimes were challenged in the GATT by five Latin American supplying countries, i. e. Colombia, Costa Rica, Nicaragua, Guatemala and Venezuela. The GATT Panel report issued on 3 June 1993, found that quantitative restrictions maintained by France, Italy, Portugal, Spain and the United Kingdom were inconsistent with GATT Article XI. 1, which provides disciplines on quantitative restrictions unless justified by other GATT provisions. In addition, the tariff preference accorded by the EC to ACP bananas in the framework of the Lomé Convention was considered by the Panel to be inconsistent with the most-favoured-nation (MFN) principle under GATT Article I, since non-ACP (i. e., third-country) bananas were subject to a customs duty not applied to ACP countries, and were, therefore, discriminated. Such a discrimination can be justified only if a waiver is granted under GATT Article XXV, according to the Panel.

The EC, together with ACP countries, blocked the adoption of the panel report. Under the GATT dispute settlement procedures, panel reports were adopted by a "positive consensus", thus a losing party had a veto in the adoption of panel reports. Shortly after blocking the panel, the EC on 1 July 1993 implemented a new Regulation 404/93 replacing the national banana regimes with the EC banana regime.

\section{Council Regulation 404/93 and the Second GATT Panel Report}

EC Regulation 404/93 established the common market regime for bananas based on preferential tariff treatment, quotas and licensing requirements for three categories of importers.

\section{(1) Categories of Imported Bananas}


Under the Regulation, imported bananas were classified into three categories : traditional ACP bananas, non-traditional ACP bananas and thirdcountry bananas. Traditional ACP bananas are those imported duty-free from twelve historical ACP supplying countries, which are broken down into country-specific duty-free "traditional quantities." Non-traditional ACP bananas consist of (i) those imported from non-historical ACP supplying countries (e.g., Dominican Republic) and (ii) those imported from historical ACP supplying countries in excess of the traditional quantities. Third-country bananas are those imported from non-ACP sources, inter alia, Latin American bananas.

These categories were used to differentiate imports with respect to tariff treatment, quota allocation and licensing requirements.

\section{(2) Tariff Treatment}

Tariff treatment for imported bananas differed considerably depending on the country category. For traditional ACP bananas, duty-free imports were guaranteed up to the maximum quantity fixed for each historical ACP supplying countries based on the Lomé Convention.

In contrast, imports of non-traditional ACP bananas and third-country bananas were subject to a tariff quota. Under the tariff quota system, a lower rate applies to in-quota imports, while a higher rate applies to out of quota imports. For non-traditional ACP bananas, an in-quota rate was free and an over-quota rate was, originally, $750 \mathrm{ECU}$ per tonne. For third-country bananas, originally, an in-quota rate was $100 \mathrm{ECU}$ per tonne, but an over-quota rate was 850 ECU per tonne, almost import-prohibitive.

While, the tariff quota, unlike quantitative restrictions, is permitted under the GATT, tariff treatment under the tariff quota is not immune from GATT disciplines. Latin American countries repeated the same arguments as in Bananas I that the tariff preferences for ACP bananas, whether traditional or non-traditional, discriminate against third-country bananas in violation of GATT Article I. 
(3) Licensing Requirements and License Allocation

Imports of all bananas were subject to licensing procedures, which vary according to the origin of bananas. The licensing procedures for EC and traditional ACP bananas were easier than those for third-country and nontraditional ACP bananas.

Import licenses for third-country and non-traditional ACP bananas at inquota rates (i. e., duty-free for non-traditional ACP bananas and at $100 \mathrm{ECU}$ per tonne for third-country bananas) were allocated based on several criteria : operator categories, activity functions etc. Of note was the license allocation rule based on operator categories.

Under the rule, the import licenses were allocated among three categories of operators based on quantities of bananas marketed during the latest three year period. While 66.5 percent of total import licenses were reserved for historical importers of third-country or non-traditional ACP-bananas ("Category A"), 30 percent was distributed to historical importers of $\mathrm{EC}$ or traditional ACP bananas ("Category B"), and 3.5 percent was allocated to new market entrants ("Category C"). Licenses for those historical importers were transferable among importers.

The 30 percent allocation rule for historical importers of EC or traditional ACP bananas incurred the objection of Latin American countries. They complained that the rule gives importers an incentive to buy $\mathrm{EC}$ or traditional ACP bananas. Under the rule, importers wishing to increase their future share of third-country or non-traditional ACP bananas at an inquota rate would be required to increase their current purchases of $\mathrm{EC}$ or traditional ACP bananas. In addition, the transferability of import licenses led importers of EC or traditional ACP bananas to sell their licenses, with high profits, to importers of third-country bananas. As affirmed by the EC Institutions, the 30 percent allocation rule was designed to "cross-subsidize" historical importers of EC or traditional ACP bananas with tariff quota rents and, thereby, offset the higher costs of production of those bananas. As a result, the discrimination against third-country bananas in favour of 
EC or ACP bananas inevitably arose from the rule, according to Latin American countries.

\section{(4) The Second GATT Panel Report ("Bananas II")}

The EC banana import regime triggered a second complaint by the same five Latin American countries as those in Bananas I. The Panel in its Bananas II report submitted on 18 January 1994 also determined the EC regime to be inconsistent with the GATT.

(i) Tariff Treatment

The Panel accepted the complainants' arguments that the tariff treatment of third-country bananas was inconsistent with GATT rules. First, a tariff for third-country bananas, whether in-quota (100 ECU per tonne) or over-quota (850 ECU per tonne) exceeded 20 percent ad valorem as consolidated by the EC in the GATT since 1963, and were, therefore, inconsistent with GATT Article II on the tariff binding. Second, as already shown in Bananas I, the tariff preferences accorded by the EC to ACP bananas discriminated against third-country bananas, being inconsistent with GATT Article I. 1.

\section{(ii) Tariff Quota System}

The complainants argued that the tariff quota system constituted quantitative restrictions prohibited under GATT Article XI. 1. The panel rejected the arguments. Measures which permit imports under a lower rate up to a certain quota and allow additional imports at a higher rate are not equated with quantitative restrictions. The higher over-quota rate, even import-restrictive, is not a quantitative restriction. Finally, the panel determined that the scheme of non-automatic licensing for in-quota imports is permitted under GATT rules since it does not alter the nature of the tariff quota.

\section{(iii) License Allocation}

However, the license allocation rule under the tariff quota, inter alia, the 30 percent allocation rule was found to be GATT-inconsistent by the panel. 
EC Banana Dispute and the GATT/WTO (KOMURO)

Consistent with the complainants' arguments, the panel held that the 30 percent allocation rule requires importers to buy domestic or traditional ACP bananas to obtain the right to import third-country bananas at a lower in quota rate. Such requirement infringes two kinds of non-discrimination principle under the GATT. First, the requirement to buy domestic bananas under the rule discriminated third-country bananas in violation of the national treatment principle under Article III. 4. Second, the requirement to buy traditional ACP bananas under the rule discriminated non-ACP third-country bananas in violation of MFN treatment under Article I. 1. The Panel added that the 66.5 percent rule, although including incentives to continue importation of third-country bananas, could not offset or legally justify the inconsistencies of the licensing system.

Once again, the adoption of Panel report was blocked by the EC under the GATT positive consensus rule.

\section{Further Developments}

Two important developments after the blocking of the Bananas II should be considered:the conclusion of the Framework Agreement on Bananas (BFA) and the grant of the Lomé waiver.

\section{(1) BFA}

In parallel with the Bananas II panel proceedings, the EC negotiated the BFA with the five Latin American complainants. The EC offered to the complainants the BFA on the premise that they abandon future GATT action against the EC banana regime. Four of the five complainants, i. e., Colombia, Costa Rica, Venezuela and Nicaragua, accepted the EC's offer by signing the BFA on 28 March 1994. They agreed not to pursue the adoption of the second Banana Panel report, and not to initiate any dispute settlement procedures against the EC banana regime until the end of 2002 . Guatemala, one of the five complainants in Bananas II, declined to accept the BFA. 
The BFA, therefore, contained a quota allocation rule that was advantageous to the four BFA countries. Under the rule, imports of non-traditional $\mathrm{ACP}$ and third-country bananas at an in-quota rate were allocated among supplier countries as follows :

- Country-specific quota allocation for BFA countries 49.4 percent of the imports was allocated to the four BFA countries. Each BFA country was apportioned an individual quota to be imported at an in-quota rate.

- Global quota allocation for non-BFA third-countries 46.5 percent of the imports was left in blanket for non-BFA third countries (e.g. Guatemala). They were classified as an "others" category.

- Country-specific quota allocation for non-traditional ACP suppliers

90,000 tonnes, reserved for duty imports of non-traditional ACP bananas, were allocated, on a country-specific basis, to (i) nontraditional quantities from three historical suppliers (Belize etc.), and (ii) non-historical suppliers (Dominican Republic and others).

This quota allocation led Guatemala (and other non-BFA countries) to argue that the BFA quota allocation discriminated against non-BFA third countries, according more favourable treatment to the BFA countries. The conclusion of the BFA resulted in discrimination among third countries (BFA and non-BFA third countries) as opposed to the previous discrimination among $\mathrm{ACP}$ and third countries. The BFA was incorporated into the EC's Uruguay Round Schedule in March 1994 and came into force on 1 January 1995. 
(2) Lomé Waiver

As demonstrated in the Bananas I and II, the only way to legitimize the tariff preference for ACP bananas under the Lomé Convention was to seek a GATT waiver. The EC and ACP countries in October 1994 requested a waiver from the EC's obligations under Article I:1 of GATT. The waiver was granted by the GATT Contracting Parties on 9 December 1994. The waiver decision provided that Article I. 1 "shall be waived, until 29 February 2000, to the extent necessary to permit the European Communities to provide preferential treatment for products originating in ACP States, without being required to extend the same preferential treatment to like products of any other contracting party." In October 1996, the Lomé waiver was extended until 29 February 2000.

\section{WTO Dispute Settlement Procedures on the Banana Dispute}

WTO procedures on the EC banana regime occurred in two phases:(i) panel and appellate body proceedings; and (ii) implementation of the Dispute Settlement Body's (DSB) recommendations.

\section{Panel and Appellate Body Proceedings}

(1) The Third Panel Report (Bananas III)

The Panel report circulated on 22 May 1997 determined that the EC banana regime was inconsistent with WTO rules. After admitting the locus standi of the United States, the Panel examined numerous substantive issues and found the WTO-inconsistency with regard to a majority of issues. The substantive issues were divided into four sections:tariff treatment, BFA quota allocation, license allocation rule and GATS issues.

(i) Tariff Treatment

The EC considered that the inconsistency of tariff preferences to ACP bananas with GATT Article I. 1 was waived by the Lomé waiver. The complainants, however, argued that the inconsistency of the tariff prefer- 
ences for non-traditional ACP bananas was not waived. The Panel rejected the complainants' arguments by referring to Article 168(2)(a)(ii) of the Lomé Convention. This provision requires the EC to grant preferential treatment to all ACP agricultural products including ACP bananas. The Panel thus concluded that the inconsistency of tariff preferences for non-traditional ACP bananas was covered by the Lomé waiver and justified under the WTO.

In contrast to the tariff treatment, the BFA quota allocation and license allocation rules were found to be inconsistent with WTO rules.

(ii) BFA Quota Allocation

In the opinion of the complainants, the BFA quota allocation in favour of $\mathrm{BFA}$ countries was inconsistent with the non-discrimination principle under GATT Article XIII. Article XIII requires that, like a quantitative restriction, a tariff quota share be allocated among WTO Members in a nondiscriminatory manner. To this end, the importing country may seek agreement with all supplying countries with a substantial interest in supplying the product concerned ("substantial suppliers"). If the agreement is not reasonably practicable, then an unilateral allocation of a tariff quota share to substantial suppliers must be made. This means that the quota allocation based on the agreement with some substantial suppliers is prohibited, as it discriminates other substantial suppliers.

The complainants submitted two-pronged arguments: the argument on substantial suppliers and that on non-substantial suppliers (e.g. supplying countries with a small import share).

First, the complainants contested the legality of the BFA quota allocation to two BFA substantial suppliers (i. e., Colombia and Costa Rica). In the view of the complainants, the EC did not reach agreement with all GATT substantial suppliers, and, consequently, the quota allocation failed to meet the requirements under Article XIII. 2(d). Article XIII. 2(d) requires that a quota allocation be made so that the allocated quota approaches "as closely as possible the shares which the various Members might be ex- 
pected to obtain in the absence of such restrictions." The Panel, however, decided to make no finding on whether the BFA allocation is consistent with Article XIII. In the Panel's view, if the Panel findings on other issues on quota allocation were adopted by the DSB, the EC would be forced to reconsider its quota allocation system.

The second argument raised by the complainants centered upon the quota allocation for non-substantial suppliers. According to the Panel, the non-discrimination principle under Article XIII permits the importing country to allocate a tariff quota share to all non-substantial suppliers in the form of an "others" category without specific shares. Nevertheless, the EC allocated country-specific quota shares to two BFA non-substantial countries (i. e., Nicaragua and Venezuela) without allocating such shares to other third countries (e.g., Guatemala). The Panel held that such discriminatory quota allocation against non-BFA third countries is inconsistent with Article XIII.

In addition, the Panel pointed out the inconsistency of the so-called quota reallocation under the BFA with Article XIII. Under the BFA, if BFA countries are unable to deliver the allocated quantity, the amount of short-fall could be reallocated to BFA countries. Such special rights in respect of reallocation of tariff quota shares were not given to non-BFA third countries (e. g. Guatemala).

(iii) License allocation

The Panel examined license allocation rules in light of GATT and WTO Licensing Agreement.

First, the Panel agreed with the finding of the unadopted Bananas II that the operator category-based license allocation rule, inter alia the 30 percent allocation rule, is discriminatory. Under the rule, because 30 percent of import licenses allowing the importation of third-country and non-traditional ACP bananas at an in-quota rate are allocated to historical importers of EC or traditional ACP bananas, those importers would be required to maintain or increase their current purchases of EC or traditional ACP bana- 
nas to obtain in-quota import licenses of third-country or non-traditional ACP bananas. Accordingly, third-country bananas were less favourably treated than EC and ACP bananas. The inconsistency of the rule with the national treatment (Article III.4) and the MFN treatment (Article I. 1) was thus reaffirmed by the Panel. Such inconsistency with the MFN treatment cannot be waived by the Lomé waiver. In the view of the Panel, because waivers should be interpreted narrowly in accordance with past panel practice, the Lomé waiver does not apply to the licensing allocation rules.

Second, the Panel analyzed the license allocation rule based activity functions. Under the EC banana regime, import licenses for third-country and non-traditional bananas were also allocated based on economic activities (i. e., primary importation, secondary importation and ripening). Such activity function-based license allocation rule applies only to third-country and non-traditional ACP bananas, but not to traditional ACP bananas. The Panel, therefore, found that, under the rules, third-country and non-traditional ACP bananas are treated less favourably than traditional ACP bananas in violation of the MFN principle (Article I.1).

Third, the BFA export certificates rule was examined by the Panel. For imports from three BFA countries (i. e., Colombia, Costa Rica and Nicaragua) into the EC, importers of third-country and non-ACP bananas were required to present export certificates issued by BFA countries. The $\mathrm{BFA}$, therefore, let BFA countries manage export certificate system and, thereby, gives BFA countries a commercial advantage compared to nonBFA third countries. Non-BFA third countries complained that the export certificate system discriminates against non-BFA countries in favour of BFA countries. The Panel accepted the complainants' arguments. In its view, "the requirement to match BFA export certificates with EC import licenses" under the export certificates rule amounts to "an advantage or privilege" in the terms of GATT Article I.1. Since this advantage is accorded only to BFA countries, but not to non-BFA third countries, the Panel concluded that the BFA export certificates requirement is inconsistent with the MFN 
principle under GATT Article I. 1.

Finally, the "hurricane license" rule was also found to be WTO-inconsistent. The EC issued "hurricane licenses" each time a tropical storm caused damage to the banana plantations in the EC (Guadeloupe, Martinique, etc.) and ACP countries and greatly affected supplies to the Community market. In the aftermath of several hurricanes, additional import licenses of third-country or non-traditional ACP bananas were authorized by Commission Regulations since 1994. The licenses were allocated only to EC and ACP producers or importers. The exclusion of third-country operators from enjoying the hurricane licenses led Latin American countries to complain about the discriminatory allocation of the hurricane licenses.

The Panel held that the exclusive issuance of hurricane licenses to EC or traditional ACP producers are inconsistent with the national treatment (GATT Article III.4) and the MFN treatment principles (GATT Article I. 1). However, as far as the exclusive issuance of hurricane licenses to traditional ACP producers is concerned, the Panel added that the inconsistency with the MFN treatment is waived by the Lomé waiver. This means that the exclusive issuance of hurricane licenses to EC producers is still inconsistent with the national treatment principle.

The Panel further considered that the exclusive issuance of hurricane licenses to EC or traditional ACP producers are also inconsistent with Article 1.3 of the Licensing Agreement. Article 1.3 provides that the import licensing procedures shall be "neutral in application." The requirement of neutral application precludes the imposition of different import licensing procedures according to the country of origin of products. The Panel, therefore, held that the issuance of hurricane licenses exclusively to ACP and EC producers, but not to third-country producers, is inconsistent with the requirement of neutral application. In addition, such inconsistency cannot be waived by the Lomé waiver. As noted by the Panel, the Lomé waiver was initially granted by the GATT Contracting Parties without a power over the Tokyo Round Agreement on Import Licensing Procedures 
and the latter Agreement contained no waiv er provision.

\section{(iv) GATS Issues}

The complainants claimed that the EC license allocation rules infringe not only the GATT on trade in goods but also the GATS on trade in services. The rules were alleged to discriminate against distributors of third-country and non-traditional ACP bananas to protect distributors of EC and traditional ACP bananas. As a result, EC and ACP-owned distributors were provided competitive advantages compared to third-country-owned distributors, inter alia, North and South American traders. In the view of the complainants, such discrimination in favour of EC and ACP-owned service suppliers was inconsistent with national treatment and MFN principles as embodied in Articles XVII and II of GATS, respectively. The complainants considered banana distributors to be suppliers of "wholesale trade services", a service sector in which the EC has undertaken a full commitment on national treatment and MFN obligations.

The EC responded that the license allocation rules are "measures directed at trade in goods and not trade in services" and, therefore, fall outside the purview of the GATS. According to the EC, the measure cannot be covered by both GATT and GATS, those coverage being exclusive. Consequently, the EC denied the alleged discrimination against complainants' service suppliers under the GATS.

The Panel supported the complainants' arguments. The Panel began to clarify that the import licensing procedures in question are covered by the GATS, which apply to "any measures bearing upon conditions of competition in supply of a service." To put the Panel's reasoning succinctly, the coverage of GATT and GATS is not mutually exclusive, but concurrent.

The Panel, then, considered the distribution of bananas to be "wholesale trade services" as inscribed in the EC's GATS Schedule of Commitments and found that the EC is fully bound by its MFN and national treatment obligations in the sector of wholesale trade services. In addition, the MFN obligation should be interpreted, added the Panel, as a require- 
ment to provide, to service suppliers of any other Member, "conditions of competition" no less favourable than those accorded to any other country's service suppliers. No less favourable treatment under the MFN clause was equated with no less favourable conditions of competition.

Based on such basic considerations, the Panel examined whether the EC license allocation rules were inconsistent with the MFN and national treatment principles under the GATS.

First, the operator category-based license allocation rule, inter alia, the 30 percent allocation rule was found, by the Panel, to be discriminatory under the GATS. As explained above, the rule was considered to be discriminatory under the GATT, since it requires historical importers of EC or ACP bananas to buy EC or ACP bananas (but not third-country bananas). However, under the GATS, the discriminatory nature of the rule was affirmed in that the rule leads historical importers of EC or traditional ACP bananas to sell import licenses, with high profits, to historical importers of third-country bananas. Because importers of EC or traditional ACP bananas are "most often" EC or ACP-owned service suppliers, while importers of third-country bananas are most often third-country-owned service suppliers, the complaints' service suppliers were, under the rule, subject to less favourable conditions of competition than EC or ACP-owned service suppliers in the violation of national treatment and MFN principles, according to the Panel. Although the rule "arguably appli(es) on a formally identical basis to all service suppliers regardless of their nationality, ownership or control," the Panel considered that such formally identical measure, nevertheless, gives rise to a discrimination.

Second, the activity function-based license allocation rule was found to be inconsistent with the national treatment principle. Under the rule, import licenses allowing the importation of third-country and non-traditional ACP bananas at in-quota tariff rates were allocated among three kinds of operators : primary importers, secondary importers (i. e., customs clearers) and ripeners. Whereas primary importers and secondary importers were 
allocated 57 and 15 per cent of import licenses, respectively, 28 percent was reserved for ripeners that are overwhelmingly EC owned or controlled. However, the transferability of import licenses permits ripeners to sell, with high profits, to primary importers and, thereby, reap tariff quota rents. Consequently, the allocation to ripeners, most often EC-owned service suppliers, of 28 percent of the import licenses created less favourable conditions of competition for primary importers, most often third-country-owned service suppliers, in the violation of the national treatment principle.

Third, the BFA export certificates rule was considered to be in breach of the national treatment and MFN principles. The rule required importers of third-country and non-traditional ACP bananas to match EC import licenses with BFA export certificates with respect to imports from three BFA countries. However, importers of EC and traditional ACP bananas were exempted from such requirement so that they could import BFA bananas without presenting export certificates. Given that importers of third-country bananas are most often third-country-owned service suppliers, whereas importers of EC or traditional ACP bananas are most often EC or ACP-owned service suppliers, the exemption of importers of EC and traditional ACP bananas from the requirement created less favourable conditions of competition for third-country-owned service suppliers than EC and ACPowned service suppliers, according to the Panel.

Fourth, the allocation of hurricane licenses was found by the Panel to be GATS-inconsistent. Under the EC regime, the hurricane licenses were exclusively allocated to "operators who include or directly represent EC or ACP producers or producer organizations" affected by a tropical storm. Although the allocation rule applies "on an arguably formally identical basis" to services suppliers "regardless of their origin, nationality, ownership or control," because the vast majority of operators who include or directly represent $\mathrm{EC}$ or $\mathrm{ACP}$ producers are $\mathrm{EC}$ or ACP-owned service suppliers, the allocation rule was found to be discriminatory against third-country-owned service suppliers in the violation of national treatment and MFN 
principles.

(2) The Appellate Body Report

The EC appealed most of the Panel's legal findings. The complainants, although supporting the Panel's findings on major issues, also raised several issues in the appeal. The Appellate Body, in its report circulated on 9 September 1997, upheld almost all the Panel's findings, modifying or reversing some points.

One of points reversed by the Appellate Body was related to the scope of Lomé waiver. The Panel held that Lomé waiver waives the inconsistency of the EC quota allocation preferences for ACP bananas with GATT Article XIII on non-discriminatory administration of tariff quota. The Appellate Body reversed this conclusion, limiting its coverage to the inconsistency with GATT Article I. 1.

\section{(3) The DSB Recommendation}

The DSB on 25 September 1997 adopted the Appellate Body report and the Panel report, as modified by the Appellate Body report, through the so-called "negative consensus" rule. Unlike under the GATT, WTO panel reports are automatically adopted at a DSB meeting unless unanimously rejected. The adoption of the Appellate Body reports is also made by the DSB under the negative consensus rule. In contrast to the GATT positive consensus rule which permitted the losing party to block the adoption of panel reports, the WTO negative consensus rule precluded the losing party from blocking the adoption of panel or Appellate Body reports.

The DSB recommended the EC to bring the banana import regime into consistency with the EC's obligations under the GATT and the GATS. 


\section{Implementation of the DSB Recommendations}

(1) Reasonable Period of Time for Implementation and EC's Implementing Measures

The complainants on 17 November 1997 requested that the "reasonable period of time" for implementation of the DSB recommendations be determined by binding arbitration. The arbitrator on 7 January 1998 concluded that the reasonable period of time would expire on 1 January 1999.

To implement the DSB recommendation, the EC adopted (i) Council Regulation $1637 / 98$ of 20 July 1998 amending the Regulation 404/93 on the EC banana regime and (ii) Commission Regulation 2362/98 of 28 October 1998 laying down detailed rules for the implementation of Council Regulation 404/93. Consultations were held between Latin American countries (Ecuador, the United States etc.) and the EC regarding a question of whether the EC implementing measures are WTO-consistent, but failed to result in a mutually satisfactory solution of the matter. Nevertheless, Regulations $1637 / 98$ and $2362 / 98$ were to enter into force on 1 January 1999.

\section{(2) Consistency Issue (DSU Article 21.5 Proceeding)}

Pursuant to Article 21.5 of the WTO Dispute Settlement Understanding (DSU), the EC and Ecuador in mid-December 1998 requested the DSB to re-establish the original panel (i. e., the Bananas III Panel) to solve a dispute over a question of WTO-consistency of the EC implementing measures. Whereas the EC asked the panel to determine that the EC implementing measures must be presumed to conform to WTO rules, Ecuador requested the panel to examine the $\mathrm{EC}$ implementing measures in the light of GATT, GATS and the Licensing Agreement. On 12 January 1999, the DSB re-established the original panel to deal with both Ecuador's and the EC's requests. The original panel requested by the $\mathrm{EC}^{9}$ concluded that the EC implementing measures cannot be presumed to be consistent with the WTO rules because of findings by the same panel requested by Ecuador. The latter, in its report circulated to the parties on 6 April 1999, found the 
EC Banana Dispute and the GATT/WTO (KOMURO)

10)

EC implementing measures to be WTO-inconsistent.

(3) WTO-inconsistency of the EC Implementing Measures

The EC implementing measures provided for the following banana import regime.

(i) Traditional ACP imports

Imports of traditional banana imports from twelve ACP countries were duty-free up to an annual limit of 857,700 tonnes. The country-specific allocations for each of the twelve ACP countries, being found to be GATT. inconsistent by the Bananas III panel, was eliminated.

(ii) Third-country and non-traditional ACP imports

For imports of third-country and non-traditional ACP bananas, a tariff quota system was maintained. Imports of non-traditional ACP bananas were duty-free up to 240,748 tonnes, but were subject to 537 Euro per tonne for an over-quota quantities. In contrast, imports of third-country bananas (i. e., non-ACP third-country bananas) were subject to 75 Euro per tonne up to an in-quota quantities (i. e., 2.553 million tonnes) and 737 Euro per tonne for an over-quota quantities, respectively. Imports of third-country bananas at an in-quota tariff rate were allocated to four substantial suppliers and an "others" category for non-substantial suppliers. Four substantial suppliers consist of two ex BFA countries (i. e., Colombia and Costa Rica) and two new WTO Members (i. e., Ecuador and Panama). The "others" category was reserved for third-country bananas as well as nontraditional ACP bananas. The previous import licensing procedures and licence allocation rules were eliminated.

The original panel requested by Ecuador found the EC's revised banana regime to be still WTO-inconsistent for the following reasons.

(i) Inconsistency with GATT Article XIII on non-discriminatory administration of tariff quota.

The Panel considered the 857,700 tonne limit on duty-free imports of traditional ACP bananas to be a tariff quota subject to Article XIII. 
However, this limit exceeded the average exports during the past three-year period and, therefore, did not approach "the shares which various Members might be expected to obtain in the absence of restrictions" as required by Article XIII. 2(d), according to the Panel.

The Panel further held that imports from non-substantial suppliers were not similarly restricted in the meaning of GATT Article XIII. 1. On the one hand, ACP non-substantial suppliers could benefit from access to the "other" category of the MFN tariff quota once the 857,700 tonne tariff quota was exhausted. On the other hand, third-country non-substantial suppliers have no access to the 857,700 tariff quota once the "other" category of the MFN tariff quota was exhausted.

In respect to tariff quota allocation, added the Panel, the country-specific allocations to substantial suppliers including Ecuador was made based on the non-representative period in violation of GATT Article XIII :2.

(ii) Scope of Lomé Waiver

Duty-free treatment of traditional ACP imports "in excess of an individual ACP State's pre-1991 best-ever export volumes," being not required under the Lomé Convention, was found to be not covered by the Lomé waiver. In contrast, (i) non-traditional ACP imports at zero tariff within the "other" category of the tariff quota and (ii) the margin of tariff preference of 200 Euro per tonne for over-quota imports were required under the Lomé Convention, and therefore, was found to be covered by the Lomé waiver.

(iii) GATS

The Panel held that Ecuador's suppliers of wholesale services were accorded de facto less favourable treatment in respect of licencs allocation than EC/ACP suppliers of those services in violation of MFN (Articles II) and national treatment (Article XVII) principles. In addition, the Panel considered that the criteria for acquiring "newcomer" status under the revised licensing procedures accorded to Ecuador's service suppliers de facto less favourable conditions of competition than to like EC service suppliers in violation of the national treatment principle. 


\section{(4) Retaliation Issue}

In parallel with, and even prior to the implementation stage and determination of EC consistency, the retaliation issue was raised in the DSB. Under the WTO Dispute Settlement Understanding, a winning party may take retaliation against a losing party which fails to implement the DSB recommendation if the DSB authorizes retaliation in accordance with the negative consensus rule.

The United States requested, on 14 January 1999, authorization from the DSB to retaliate against the EC in an amount of US\$520 million. The EC objected to the level of retaliation proposed by the United States on the ground that it was not equivalent to the level of nullification or impairment of benefits suffered by the United States. Pursuant to Article 22.6 of the DSU, the EC requested, on 29 January 1999, arbitration on the level of retaliation requested by the United States. The DSB referred the issue of the level of retaliation to the original panel for arbitration. Pursuant to Article 22.6 of the DSU, the request for the suspension of concessions by the United States was deferred by the DSB until the determination, through the arbitration, of the appropriate level for the retaliation.

The arbitrators found that the level of retaliation sought by the United States was not equivalent to the level of nullification suffered as a result of the EC implementing measures. The level of nullification suffered by the United States was determined, by the arbitrators, to be equal to US $\$ 191.4$ million. The arbitrator's report, together with the original panel's reports on the WTO-inconsistency of the EC implementing measures, were issued to the parties on 6 April 1999, and circulated to Members on 9 and 12 April 1999 respectively.

On 9 April 1999, the United States, pursuant to Article 22.7 of the DSU, requested that the DSB authorize retaliation against the EC, which is equivalent to the level of nullification, i.e. US\$191.4 million. On 19 April 1999, the DSB authorized the United States to retaliate against the EC as requested. This was the first sanction authorized under the WTO. 
(5) EC Reform of Banana Regime

Under pressure from the U.S. retaliation, the EC began to reform the banana regime. At the DSB meeting on 19 November 1999, the EC informed the DSB of its proposal for amendment of the banana regime. The proposal envisages a two-stage process : a tariff quota system for several years and a tariff-only system from 1 January 2006. The proposal includes a decision to continue discussions with interested parties on the possible systems for allocation of licences for the tariff quota shares. If no feasible system can be found, the proposal for a transitional tariff rate quota regime would not be maintained and negotiations under GATT Article XXVIII would be envisaged to replace the current system with a tariff only regime.

The WTO dispute settlement procedure as shown above seems to prove itself effective to pursue a major country's trade measure inconsistent with the WTO.

\section{ECJ's and National Courts' Judgments on the Banana Dispute}

\section{German Problem}

The EC banana regime gave rise to numerous proceedings in the ECJ and national courts. The root cause of most proceedings lied in economic losses suffered by operators of third-country bananas, inter alia German importers of Latin American bananas, following the introduction of Regulation 404/93. The Regulation deprived the German importers of a right, under the old Banana Protocol, to import duty-free third-country bananas and, instead, subjected them to a tariff quota system. Under the system, German importers, classified as historical importers of third-country bananas, were allocated licenses for importing third-country bananas at an in-quota tariff rate. The problem was that, in addition to a newly imposed tariff burden, a considerable reduction of import quantities hit German importers. Their imports of Latin American bananas decreased, by nearly 40 percent, 
from $1,371,000$ tonnes in 1992 to 840,000 tonnes in 1994. Such decrease arose from the license allocation rule, which reserved 30 percent of the tariff quota licenses to historical importers of EC or traditional ACP bananas. In reality, however, those importers could not import third-country bananas in the absence of relationships with third-country producers. The relationships between producers and importers were based on long-term contracts, which were in turn secured by long-running investments. As a result, importers of $\mathrm{EC}$ or traditional $\mathrm{ACP}$ bananas sold dear their licenses to German importers and the latter passed costs on to German consumers.

The banana regime was thus a model for the failure of dirigiste regulations in that it violated the rules of market economics, according to U. Everling. Notwithstanding the formal achievement of the internal market, trade in bananas between Member States was limited. The World Bank study concluded that the common banana regime was as inefficient as the previous national market arrangements.

Not surprisingly, the issue on the lawfulness of the EC banana regime was raised mainly by the German Government and German importers in the EC.

2. Action by the German Government before the ECJ

(1) Action for Annulment of Regulation 404/93

In Germany v. Council, the German Government, supported by interventions from Belgium and the Netherlands, presented numerous formal and material arguments. Of those arguments, the following three pleas were pertinent:

- The allocation the tariff quota constitutes unjustified discrimination against historical importers of third-country bananas;

- The loss of the market shares of those importers constitutes an infringement of their property rights and their rights to pur- 
sue their business; the regulation violates the principle of proportionality ;

- Certain provisions of GATT were infringed.

The European Court in its judgment of 5 October 1994) rejected these pleas based on the following reasoning.

(i) Plea on a discrimination

Under the previous national import regimes, open national markets and closed national market co-existed and the situations of economic operators were not comparable. Accordingly, the Regulation 404/93 affected economic operators differently. However, "such a difference in treatment appears to be inherent in the objectives of integrating previously compartmentalized markets" by the Regulation. Therefore, a different treatment of imports of third-country bananas does not infringe the principle of non-discrimination as provided for in ex Article 40 (3) of the EC Treaty.

(ii) Plea on the right to property and the freedom to pursue a trade

The right to property and the freedom to pursue a trade form part of the general principles of Community law. However, they are not absolute and may be restricted in the context of a common organization of a market, "provided that those restrictions in fact correspond to objectives of general interest pursued by the Community and do not constitute a disproportionate and intolerable interference, impairing the very substance of the rights guaranteed."

With regard to the right of property, no economic operator can claim a property in a market share which he held before the implementation of the contested regulation, since it constitutes "only a momentary economic position exposed to the risks of changing circumstances." In addition he cannot claim an acquired right or legitimate expectation to the maintenance of an existing situation, especially if the latter is contrary to the rules of the Common Market. 
Regarding the freedom to pursue a trade, the competitive position of German importers was altered by the Regulation that limited imports of third-country bananas. However, such limitation is justified by "the general interest of the Community" to replace the divergent national regimes with the common market organization of the market.

The plea of a breach of proportionality must also be rejected. Given the broad discretion of the Community legislature in the field of common agricultural policy, implementing measures are open to criticism only if the assessment of their future effects "appears manifestly incorrect in the light of the information available at the time of the adoption of the (measures) in question." The German government could not show that "the Council adopted measures which were manifestly inappropriate or that it carried out a manifestly erroneous assessment."

(iii) Plea of a breach of GATT provisions

The German government argues that, in the direct action by a Member State, Community acts are void if they do not comply with GATT rules, "regardless of any question as to the direct effect of GATT." By contrast, the Council refutes that GATT cannot be relied on to challenge the lawfulness of a Community act in the absence of direct effect, except in special cases. The Court agrees with the Council. As shown in the established case law, GATT provisions have no direct effect so that the German Government cannot invoke GATT provisions to challenge the lawfulness of provisions of the Regulation.

The Court was criticized by many scholars for rejecting all pleas without sufficient reasoning. The Court's reasoning for judging the Regulation to be consistent with the general principles of Community law did not convince some European lawyers. In addition, the Court's view on the direct effect of GATT caused controversy.

Three observations should be made with respect to the direct effect issue.

First, the Court denied the direct effect of GATT provisions in accord- 
ance with its established case law. According to this case law, "the provisions of GATT have the effect of binding the Community", but "in assessing the scope of GATT in the Community legal system the spirit, the general scheme and the terms of GATT must be considered." The GATT 1947 is based on the principle of negotiations and is characterized by the great flexibility, the measures in case of exceptional difficulties and the dispute settlement. Those features of GATT explain why GATT provisions have no direct effect.

Second, the Court stated that, in the absence of the direct effect of GATT provisions, not only an individual cannot invoke them in a national court to challenge the lawfulness of a Community act, but also the Court is precluded "from taking provisions of GATT into consideration to assess the lawfulness of a regulation in an action brought by a Member State."

This finding was criticized by U. Everling. In his view, the direct effect issue is relevant to individuals before national courts, but not to a Member State before the ECJ. He stressed:

"The Member States are competent to seize the Court even if their interests are not involved $\cdots$ Their right to go to the Court is not only given to them to protect their own rights but also that they may intervene to supervise the legality of Community law."

In contrast, Eeckhout defended the Court, stating:

" $(\mathrm{T})$ he Community's legal order could not sustain a differentiated approach towards the requirement of direct effect, by not imposing it in direct actions for annulment before the Community courts. Where the lawfulness or validity of a Community act is challenged, the success of such a challenge should not depend on the route by which it is brought before the Community courts. Neither should it depend on whether the plaintiff is a Community institution, a Member State or an individual. Acts are lawful or unlawful, and that is why the Court of Justice, in general, aims to adopt the same approach for indirect challenges, by way of a reference, and direct challenges." 
The denial of direct effect of GATT provisions thus exempted the Court from reviewing the Regulation in the light of GATT provisions. The Regulation was already found to be GATT-inconsistent by the Bananas II Panel, which was submitted to the parties in mid-January 1994 and was definitively tabled following the March 1994 BFA commitments.

The final remark on the direct effect issue is that the Court, consistent with its jurisprudence, demonstrated surrogates for a denial of direct effect. The lawfulness of a Community act can be reviewed from the point of view of the GATT/WTO rules even regardless of whether relevant provisions of GATT rules have not direct effect. There are two hypotheses permitting such a review:(i) cases where the Community act expressly refers to specific provisions of GATT; and (ii) those where the Community intended to implement a particular obligation entered into within the framework of GATT.

\section{(2) Action for Annulment of the BFA Decision}

The German Government also challenged the BFA. It made request to the Court under ex Article 228 (6) of the EC Treaty for an opinion on the compatibility of the BFA with the EC Treaty. However, the Court in its opinion of 13 December 1995 rejected the request, stating that the request has become devoid of purpose because the BFA, incorporated in the WTO Agreements, was concluded after the request for an opinion was submitted to the Court.

In contrast, the direct action for annulment of the BFA Decision by the German Government partially succeeded. The Court of Justice on 10 March 1998 annulled a provision of Council Decision 94/800 of 22 December 1994 concerning the conclusion of WTO Agreements. By the provision, the Council approved the conclusion of the BFA, which contained the export-licence rule. Under the rule, importers of EC and traditional ACP bananas were exempted from the export-license system in breach of the general principle of non-discrimination. 


\section{Action by German Importers before the ECJ}

(1) Action for Annulment

In Fruchthandelsgesellschaft mbH Chemnitz v. Commission, a German fruit-trading firm filed an action for annulment of the Commission Decision rejecting the applicant's request for the grant of import licences under the transitional measures as provided for in Council Regulation 404/93. The applicant argued that the Regulation is void by the effects of the Bananas III Appellate Body Report adopted by the DSB. The CFI in its judgment of 28 September 1999 rejected the applicant's argument based on two-stage reasoning.

First, the CFI made it clear that the Bananas III Appellate Body report "does not call into question the tariff quota system as such." The report found certain discriminatory elements in the EC banana regime, but did not find the regime as a whole to be incompatible with GATT or with the GATS. Consequently, the applicant cannot rely on the report in order to claim that the EC banana regime no longer exists, according to the Court.

Second, the Court stated that the applicant has not established a link in law between the DSB recommendation and this action for annulment. Then the Court recalled the Community case-law including Germany v. Council "that, in order for a provision to have direct effect on a person other than the addressee, that provision must impose on the addressee an unconditional and sufficiently clear and precise obligation vis-à-vis the person concerned." However, "the applicant has not put forward any arguments to support the view that those criteria (for direct effect) are met." The Court, therefore, concluded that its argument should be rejected as unfounded, "without there being any need to consider whether the mandatory decisions of the Dispute Settlement Body have direct effect."

This finding implies that if the applicant succeeds in establishing the direct effect of panel reports or DSB recommendations, they can invoke them before ECJ or national courts to argue the illegality of a provision of a Community act. It, however, would be extremely difficult for traders to 
EC Banana Dispute and the GATT/WTO (KOMURO)

establish such direct effect. The reason is that the maintenance of the judgment Germany v. Council seem to demonstrate the ECJ's passivity on the direct effect issue.

\section{(2) Action for Damage}

Individuals may apply for an order under Article 235 (ex 178) and the second paragraph of Article 288 (ex 215) EC-Treaty, requiring the European Community to pay compensation for damage caused by a Community act. According to Article 288 (ex 215), paragraph 2 EC-Treaty, Community shall in the case of non-contractual liability make good any damage caused by its institutions in the performance of their duties. The contractual liability is subject to the general principles common to the laws of the Member States. As repeated by the Court, "action for damages is an autonomous form of action with a particular function to fulfill within the system of remedies provided for by the Treaty"

In Atlanta and others $\mathrm{v}$ Council and Commission, the Court of First Instance ("CFI") dismissed the importers' claims for damage that had been transferred from the ECJ to the CFI. The claims included:breach of the principle of non-discrimination; breach of the principle of protection of legitimate expectations; breach of the fundamental freedom to pursue an economic activity ; Council liability for a lawful act ; and GATT-inconsistency.

In particular, the CFI rejected the claim concerning infringement of the GATT based on the same reasoning as the judgment Germany v. Council. However, at the level of ECJ, Atlanta invoked the DSB recommendation that adopted the Bananas III Appellate Body and Panel reports. Atlanta knew the illegality of the EC banana regime by the publication of the DSB recommendation six months after initiating the appellate procedure. Atlanta argued that given the DSB recommendation, the illegality of the EC banana regime is clear. The ECJ in its judgment of 14 October 1999 rejected the claims by referring to the judgment Germany v. Council. 
It remains to be seen whether WTO Agreement provisions have direct effect under the ECJ jurisprudence. The features of WTO Agreements are different than those of GATT. As the Advocate General Tesauro in Hermès International pointed out, major innovations of the WTO Agreements (i. e, absence of a great flexibility, derogation, the dispute settlement procedure) suggest that provisions of WTO Agreements have a direct effect. However, the Advocate General, in conclusion, denied the direct effect from the viewpoint of the reciprocity. The European Court of Justice has not ruled on direct effect in the context of the WTO Agreement (inter alia, the TRIPs Agreement) in Hermès International. Certain commentators equated the attitude of the ECJ with denial of justice or judicial protectionism.

4. National Courts' Decisions including preliminary rulings of the ECJ

German importers of third-country bananas sought redress before national courts to claim additional licenses. In accordance with Article 234 (ex 177) EC-Treaty, national courts requested the ECJ to give rulings on questions concerning the validity and interpretation of the Bananas Regulation.

\section{(1) Atlanta I}

The Atlanta companies, historical importers of third-country bananas, received from the competent German authorities import quotas for third-country bananas for the period from 1 July to 30 September 1993. Since the Bananas Regulation had limited import possibilities, the Atlanta companies brought an action against these decisions of the German authorities in German courts. Some questions were presented by German courts to the ECJ.

In Atlanta Fruchthandelsgesellschaft v Bundesamt für Ernährung und Forstwirtschaft, the ECJ on 9 November 1995 rendered preliminary rulings. In particular, the judgment (Case C-466/93) answered the question of valid- 
EC Banana Dispute and the GATT/WTO (KOMURO)

ity of the Bananas Regulation by repeating the reasoning of the judgment Germany v. Council.

\section{(2) T. Port I}

T. Port, a traditional importer of third-country bananas, obtained from the competent German authorities licenses to import third-country bananas for the second half of 1993 and for 1994 and 1995. In 1994 T. Port, arguing that it was suffering hardship, requested additional licenses from the authorities. Applications for interim relief were, however, dismissed by the Verwaltungsgericht (Administrative Court) Frankfurt am Main. The decision of the Verwaltungsgericht was confirmed by the Hessischer Verwaltungsgerichtshof of 23 December 1994.

(i) BverfG's Order

Port brought a constitutional appeal before the Bundesverfassungsgericht ("BVerfG" Federal Constitutional Court). The BVerfG, by order of 25 January 1995, quashed the decision of the Hessischer Verwaltungsgerichtshof on the ground that it had not taken into account the fact that the Regulation, in particular Articles 16 and 30 thereof, was capable of covering cases of hardship. The BVerfG held that the Verwaltungsgerichtshof should have considered whether the fact that Port was threatened with bankruptcy constituted an irreparable infringement of the right to property guaranteed by Article 14 of the Grundgesetz (Basic Law). It based its ruling on Article 19(4) of the German Basic law, which demands effective judicial protection including provisional measures, particularly if the applicant is in danger of bankruptcy.

Pursuant to the order of the BVerfG, the Hessischer Verwaltungsgerichtshof, by order of 9 February 1995, varied the decision of the Verwaltungsgericht Frankfurt am Main of 8 December 1994 and ordered the Bundesanstalt to issue to Port, for 1995, further import licenses.

(ii) ECR's Preliminary Ruling

The Hessischer Verwaltungsgerichtshof also referred the following 
questions to the Court for a preliminary ruling:

- Does the Bananas Regulation put the Commission under a duty to deal with cases of hardship arising because third-country operators have difficulties in continuing trading owing to the fact that they are allocated an exceptionally low quota and cannot switch to the market for ACP and Community bananas?

- In the event that the question is answered in the affirmative : on what conditions is the national court authorised to take provisional measures in proceedings for the grant of interim relief until such time as hardship arrangements are introduced?

The European Court of Justice answered that, as regards Article 30 of the Bananas Regulation, the Commission must take into consideration the situation of traders who, in the context of prior national arrangements, have taken action without having been able to foresee the consequences which that action would have after the establishment of the common organization of the markets. Such intervention would be required in particular where, in the case of some traders, the transition to the common organization infringes fundamental rights protected by Community law, such as the right to property and the right to pursue a professional or trade activity.

However, with regard to the second question, the Court of Justice stated that national courts have no jurisdiction to order interim measures pending action on the part of the Commission. If the Commission fails to intervene, only the Court of Justice or the Court of First Instance, can ensure judicial protection for the persons concerned. In such actions for failure to act, these Courts could, at the applicant' s request, adopt interim measures. Where the Commission expressly refuses to act or adopts a measure different from that which the persons concerned sought or considered to be necessary, the Member State or the trader concerned may seek 
annulment of that measure by the Court of Justice or the Court of First Instance.

As a result of this ruling, a number of traders, invoking cases of hardship, have submitted to the Commission applications for additional allocations. However, since the Commission did not react immediately, T. Port brought an action for failure to act (Article 232 (ex 175 EC-Treaty) before the Court of First Instance. This action was dismissed because the Commission adopted the necessary acts after the action was brought but before judgment.

\section{(3) T. Port II}

T. Port was not satisfied with the procedure before the Verwaltungsgerichtshof Kassel, and at the time of the orders of the Verwaltungsgerichtshof (February 1995), started proceedings against the custom administration (Hauptzollamt Hamburg-Jonas). It demanded to be permitted to import third-country bananas from Ecuador without licences and free of customs duties. When this was refused, T. Port instituted proceedings before the BVerfG (Federal Constitutional Court) against the negative decision of the Hauptzollamt Hamburg-Jonas.

(i) German Courts' Decisions

By order of 26 April 1995 the BVerfG declined to give judgment in those proceedings on the ground that $T$. Port was required first to make an application for an interim order safeguarding its rights. The BVerfG stated that it was not impossible that the court hearing the application for interim relief might, in view of the inconsistency between the Bananas Regulation and the obligations incumbent on the Federal Republic of Germany under GATT, decide not to apply that regulation for the time being. It also pointed out that the courts of appropriate jurisdiction had not yet examined the legality of the Bananas regulation.

$\mathrm{T}$. Port, in reliance on the decision of the BVerfG, again asked the Hauptzollamt Hamburg-Jonas to grant customs clearance for the consign- 
ment of bananas and to apply a lower rate of customs duty. Following a further refusal by the Hauptzollamt Hamburg-Jonas, T. Port applied to the Finanzgericht Hamburg for an interim order safeguarding its rights. T. Port claimed that the Bananas Regulation, although valid under Community law, should be regarded as legal measures adopted outside the scope of Community competence, within the meaning of the BVerfG's "Maastricht" judgment of 12 October 1993, by reason of their incompatibility with GATT. The same was true, it claimed, of the judgment in Germany v. Council, cited above, in which the Court of Justice held the Bananas Regulation to be valid. Those legal measures, which undermined the substance of $T$. Port's fundamental rights, were thus not applicable in Germany.

By order of 19 May 1995 the Finanzgericht Hamburg upheld T. Port's application and, by interim order, instructed the Hauptzollamt HamburgJonas to release into free circulation the consignment of bananas purchased by $\mathrm{T}$. Port in Ecuador, without presenting an import license and at the lower rate of duty of ECU 75 per tonne. In that order it stated that the Bananas Regulation infringed the GATT rules and that, by virtue of the first paragraph of Article 307 (ex 234) EC-Treaty, the Federal Republic of Germany was entitled not to apply, for the time being, provisions of Community law that infringed GATT. In the same order it referred questions to the Court of Justice for a preliminary ruling (Case C-182/95 T. Port v Hauptzollamt Hamburg-Jonas).

The customs authorities appealed against the decision on interim relief to the Bundesfinanzhof, which annulled the order on 22 August 1995 on the ground that no final decision had been taken in the main proceedings when the bananas were released into free circulation. It stated that provisional protection in customs proceedings has to be granted in the form of suspension of the duties. Again, T. Port appealed against that judgment to the BVerfG, where the case is pending.

The President of the European Court of Justice, by decision of 8 September 1995, stayed therefore the proceedings in Case C-182/95 T. Port 
EC Banana Dispute and the GATT/WTO (KOMURO)

v Hauptzollamt Hamburg-Jonas pending delivery of the BVerfG's judgment.

In consequence of the judgment of the Bundesfinanzhof, by decisions of 29 August and 1 September 1995 the customs authorities required post-clearance recovery of the customs duties payable on the bananas which T. Port had imported from Ecuador without presenting the requisite import licenses.

In response to applications by T. Port, the Finanzgericht Hamburg, by orders of 22 and 27 September 1995, suspended the operation of the decisions of the customs authorities of 29 August and 1 September 1995 amending customs duties, without requiring a guarantee to be furnished. The payments were suspended until such time as it received the decision of the Court of Justice on the preliminary questions it had presented at the same time.

Once more, the Bundesfinanzhof was appealed to against this, but this time it confirmed the ruling of the Finanzgericht Hamburg, in a decision of 9 January 1996. It accepted the doubts of the Finanzgericht as regards the conformity of the Bananas Regulation with GATT and the priority of the application of GATT, pursuant to Article 307 (ex 234) EC-Treaty.

The Finanzgericht Hamburg recognised that, following the judgment in Germany v Council, the Bananas Regulation must be regarded as valid under Community law. It nevertheless considered that the provisions of that regulation are contrary to certain fundamental GATT rules which the Federal Republic of Germany, as a contracting party to GATT, is required to observe.

In those circumstances, the question arose, in its view, whether, having regard to the first paragraph of Article 307 (ex 234) of the Treaty, the application in Germany of the relevant GATT rules must take precedence over the Bananas Regulation. This was therefore the question that it presented to the ECJ.

(ii) ECJ's Preliminary Ruling

The ECJ in the judgment of 10 March 1998 confirmed that the purpose of the first paragraph of Article 307 (ex 234) EC-Treaty is to make clear, 
in accordance with the principles of international law, that application of the Treaty does not affect the commitment of the Member State concerned to respect the rights of third countries under an earlier agreement and to comply with its obligations thereunder. Thus, for a Community provision to be deprived of effect as a result of an international agreement, two conditions must be fulfilled:

- The agreement must have been concluded before the entry into force of the Treaty and

- the third country concerned must derive from it rights which it can require the Member State concerned to respect.

Consequently the ECJ stated that Article 307 (ex 234) does not apply to cases involving imports of bananas from a third country which is not a party to an international agreement concluded by Member States before the entry into force of the Treaty. Such was the case before the national court. T. Port had only imported bananas from Ecuador, which was not a contracting party to GATT 1947 and did only become a member of the World Trade Organisation in 1996.

\section{(4) Atlanta II}

After the Atlanta I procedure, the Atlanta companies received from the competent German authorities ("Bundesanstalt") for the period of January to December 1995 import quotas according to the Bananas regulation. The Bundesanstalt rejected all demands for additional import licences. Meanwhile the case law of the European Courts (see Atlanta I) also hindered the Verwaltungsgericht Frankfurt, before which Atlanta brought an action, to grant interim relief.

After the period of dispute (1995) had been expired, the applicants sustained the action before the Verwaltungsgericht pleading for a declara- 
tory judgment that the Banana Regulation was invalid in Germany.

Since the Verwaltungsgericht shared the Applicants doubts as to the conformity of the Regulation with the German Basic Law, as construed especially by the "Maastricht"-judgment of the BVerfG, it submitted to the BVerfG the question of validity of the Bananas regulation in Germany. This order of January 1997 was based on a analogous application of Article 100, paragraph 1 German Basic law.

The procedure is still pending before the BVerfG, but a judgment is expected for the very near future.

\section{(5) Maastricht Judgment}

In 1993, a former official of the European Commission and four members of the European Parliament acting as private German citizens launched an attack against the Maastricht Treaty before the BVerfG. The judgment of 12 October 1993 not only opened the way for Germany's ratification of the Treaty, but also formulated rather dramatic restraints upon the future development of the European Union by its members, its political organs and the ECJ.

The BVerfG held that it can supervise (i) whether EC law protects the essentials of the fundamental rights to a degree which is comparable with the German Constitution; (ii) and whether EC law respects the limits of the competences transferred by the Member States as approved by the act of ratification of the German Parliament.

This judgment has been widely discussed in Germany. The crux was whether EC law and judgments of ECJ not corresponding to conditions set out in the Maastricht judgment are not applicable in the territory of Germany. This is all the more important for the banana dispute, since the EC banana regime is suspicious to infringe fundamental property rights under Article 14 of the German Basic law. In addition, the ECJ categorically rejected all arguments based on the respect for international obligations and for vested rights of traders. 
Therefore, German courts would be confronted with a question of whether the Banana Regulation protects the essentials of the fundamental rights and respects the limits of the competences transferred by the Member States. In this sense, the Banana case could lead to a serious conflict between the ECJ and the German Constitutional Court, and thereby endanger the principle of primacy of EC law over national laws.

\section{Conclusion}

Comparison of the dispute settlement on three levels (GATT/WTO, ECJ, national courts) revealed the followings.

First, the effectiveness of the WTO dispute settlement procedure was reaffirmed in the banana dispute. Following the adoption of the DSB recommendation, the implementation of the DSB recommendation by the EC was kept under strict surveillance in the WTO. The EC's implementing measures were found to be WTO-inconsistent and, finally, the DSB authorized the United States to take retaliation against the EC.

In contrast with the WTO panels, the ECJ found the EC banana regime to be consistent with the Community law. In Germany v. Council, the ECJ rejected the German arguments that the banana regime was void because of the breach of fundamental rights, general principles of law and GATT rules. With regard to the plea of the breach of the GATT, the ECJ concluded that the German Government could not invoke the breach of the GATT to challenge the legality of the banana regime. Likewise, the ECJ remains passive in dealing with a question of whether the WTO rules have direct effect. However, if the ECJ continues to deny the direct effect of the WTO rules without giving sufficient reasoning, it would be criticized for maintaining the deni de justice. In addition, the ECJ's insufficient judicial control over the EC trade measure would make realize the threat expressed by the so-called Maastricht judgement.

The German Constitutional Court in its Maastricht judgement claimed 
EC Banana Dispute and the GATT/WTO (KOMURO)

power to supervise whether the EC law protects the essentials of the fundamental rights to a degree which is comparable with the German Constitution, and respects the limits of the competence transferred by the Member States as approved by the act of ratification of the German Parliament. In the view of the Court, EC laws and ECJ's judgments, if failing to correspond to conditions set out in the Maastricht judgment, are not applicable in the territory of Germany. As the banana regime is suspicious to infringe fundamental property rights under Article 14 of the German Basic law, the ECJ's passivity could lead to a serious conflict between the ECJ and the German Constitutional Court, and risk to endanger the principle of primacy of EC law over national laws.

1 ) EEC-Member States' Import Regimes for Bananas, DS32/R, 3 June 1993.

2 ) O. J. No. L47, 25. 2. 1993, p. 1. The Regulation was already adopted by the Council on 13 February 1993, three days after the establishment of the Bananas I Panel.

3 ) In 1994, the EC was the world's second largest importer of bananas after the United States. Of the total consumption in the EC-12 (3.5 million tonnes), imports accounted for approximately 80 percent (2.8 million tonnes). Of all its imports, almost 74 percent (2.1 million tonnes) originated in Latin America, whilst ACP bananas represented a share of around 26 percent (0.727 million tonnes).

4) Panel on "EEC-Import Regime for Bananas", DS38/R (not adopted).

5 ) The remaining 4.09 percent $(90,000$ tonnes) were allocated to non-traditional ACP bananas.

6) European Communities-Regime for the Importation, Sale and Distribution of Bananas, Complaint by the United States, WT/DS27/R/USA, 22 May 1997; Complaint by Mexico, WT/DS27/R/MEX etc. See Gerrit Schohe, The WTO Panel Report on the EU's Banana Regime, in European Food Law Review, 245-263 (3/1997); Jack J. Chen, Going Bananas: How the WTO Can Heal the Split in the Global Banana Trade Dispute, 63 Fordham Law Review, 1283-1335 (1995); Richard Lyons, European Union Banana Controversy, 9 Florida Journal of International Law 1, 165-188 (1994); John H. Jackson, The Evolution of the WTO Dispute Settlement Mechanism and the Prospects for the Millenium Round, in Liberalisation and Protectionism in the World Trading System (Ed. Philip Ruttley et al), Cameron May, 1999, 260-269; Kees Jan Kuilwijk, The European Court of Justice and the GATT Dilemma, Nexed Editions Academic Publishers; Kees Jan Kuilwijk, The EC Banana Saga, 
in European Trade and Industry in the 21st Century, Nexed Editions Academic Publishers, 159-189.

7 ) WT/DS27/AB/R, 9 September 1997.

8 ) Article 21.3(c) of the DSU.

9 ) WT/DS27/RW/EEC, 12 April 1999.

10) WT/DS27/RW/ECU, 12 April 1999. The report was adopted by the DSB on 6 May 1999.

11) U. Everling, Will Europe Slip on Bananas? The Banana Judgement of the Court of Justice and National Courts, in Common Market Law Review (CMLR), 33, 401-437, 1996.

12) Case C-280/93, ECR [1994] I-4973.

13) Supra note 11 , at 422.

14) Piet Eeckhout, The Domestic Legal Status of the WTO Agreement:Interconnecting Legal Systems, in CMLR, 34, 1997, 24-25.

15) ECR [1995] I-4577.

16) ECR [1998] I-0973.

17) CFI, 28 September 1999, Case T-254/97.

18) Judgement of 11 December 1996, Case T-521/93, ECR [1996] II-1707.

19) Case C-53/96, Hermès International v. FHT Marketing Choice B. V., E. C. R. [1998] I3603. See Geert A.Zonnekeyn, Mixed Feelings about the Hermès Judgment, in 5 International Trade Law \& Regulation 1, 20-25 (January 1999); Panel Discussion, Is The WTO Dispute Settlement Mechanism Responsive to The Needs of The Traders?, in 32 Journal of World Trade 2, 147-165 (April 1998).

20) Judgment of the Court of 26 November 1996, T. Port GmbH \& Co. KG v Bundesanstalt fur Landwirtschaft und Ernahrung, Case C-68/95, ECR [1996] I-6065.

21) Order of 26 November 1997, T. Port v. Commission, Case T-39/97, ECR [1997] II-2125.

22) T. Port v. Hauptzollamt Hamburg-Jonas, Joined cases T-364/95 and T-365/95 (ECR [1998] I-1023.

23) BVerfGE 89, 155; [1994] 1 Common Market Law Reports 57 et seq. 


\section{Summary}

\section{EC Banana Dispute and the GATT/WTO}

\section{KOMURO Norio}

The banana dispute merits attention in that it was dealt with on three levels : the GATT/WTO, the European Court of Justice ("ECJ") and EC Member States' courts. Because the EC banana import regime discriminated against Latin America bananas to protect ACP bananas, and favored traders of traditional $\mathrm{ACP} / \mathrm{EC}$ bananas over those of Latin America bananas, it was found by GATT/WTO panels to be inconsistent with GATT/WTO rules. In contrast, the $\mathrm{ECJ}$ rejected legal challenges against the $\mathrm{EC}$ regime. The author reviewed the banana dispute before the GATT/WTO, the ECJ and national courts to compare each judicial control over the EC trade measure.

The author's conclusion can be summarized as follows:

1. Impact of the WTO on the EC Trade Policy

The banana dispute demonstrated the extent to which the EC trade policy is subject to the WTO adjudicative control. First, the EC could not block the adoption, by the Dispute Settlement Body ("DSB"), of panel and appellate body reports that found the WTO-inconsistency of the EC banana regime. Second, the implementation of the DSB recommendation by the EC was kept under strict surveillance. Third, in the absence of compliance with the DSB recommendation, the DSB authorized the United States to 
take retaliation against the EC. The WTO dispute settlement procedure therefore proved itself effective to pursue a major country's trade measure inconsistent with the WTO.

\section{Passivity of the ECJ}

In contrast with the GATT/WTO panels, the ECJ confirmed the EC banana regime. In Germany v. Council, the ECJ rejected the German arguments that the banana regime was void because of the breach of fundamental rights, general principles of law and GATT rules. With regard to the plea of the breach of the GATT, the ECJ held that the German Government could not invoke the breach of the GATT to challenge the legality of the banana regime.

The ECJ remains passive in dealing with a question of whether the WTO rules have direct effect. If the ECJ continues to deny the direct effect of the WTO rules without giving sufficient reasoning, it would be criticized for maintaining the deni de justice. In addition, the ECJ's insufficient judicial control over the EC trade measure would make realize the threat expressed by the so-called Maastricht judgement.

3. Threat of the Maastricht Judgement

The German Constitutional Court in its Maastricht judgement claimed power to supervise whether the EC law protects the essentials of the fundamental rights to a degree which is comparable with the German Constitution. As the banana regime is suspicious to infringe fundamental property rights under Article 14 of the German Basic law, German courts would be confronted with a question of whether the EC banana regulation protects the essentials of the fundamental rights. Consequently, the ECJ's passivity could lead to a serious conflict between the ECJ and the German Constitutional Court, and thereby endanger the principle of primacy of EC law over national laws. 